\title{
Aplikasi Permainan Mandarin Scrabble bagi Pemula dengan Algoritma Directed Acyclic Word Graph
}

\author{
${ }^{1}$ Leo Benny, ${ }^{2}$ Cico Valangi Monti \\ STMIK ITMI \\ Medan, Indonesia \\ ${ }^{1}$ Asengold@gmail.com, ${ }^{2}$ Valangi83@gmail.com
}

$\begin{array}{ll}\text { Diajukan } & : 22 / 10 / 2021 \\ \text { Diterima } & : 01 / 11 / 2021 \\ \text { Dipublikasi } & : 03 / 11 / 2021\end{array}$

\begin{abstract}
ABSTRAK
Scrabble merupakan permainan papan dan permainan menyusun kata yang dimainkan 2 atau 4 orang yang mengumpulkan poin berdasarkan nilai kata yang dibentuk dari keping huruf di atas papan permainan berkotak-kotak (15 kolom dan 15 baris). Kebanyakan permainan scrabble menggunakan bahasa Indonesia ataupun bahasa Inggris. Namun, belum ada permainan scrabble yang menggunakan bahasa Mandarin. Metode yang digunakan untuk penyusunan kata dalam permainan Mandarin Scrabble ini adalah algoritma Directed Acyclic Word Graph (DAWG). Penelusuran kata pada DAWG seperti pada sebuah tree atau pohon data dimana setiap awalan dan akhiran digunakan bersama-sama untuk memperkecil jumlah ruang yang diperlukan untuk menyimpan kosa kata dan juga memperkecil waktu yang diperlukan untuk me-retrieve kata. Metode pengembangan sistem yang digunakan penelitian ini adalah metode waterfall dengan perangkat bantu yang digunakan untuk memodelkan sistem adalah flowchart diagram, activity diagram dan use case diagram. Aplikasi permainan Scrabble berbahasa Mandarin ini dapat digunakan untuk membantu pemakai dalam mempelajari mengenai cara pelafalan (pembacaan) dan mengenal intonasi dari karakter dalam bahasa Mandarin. Aplikasi permainan Mandarin Scrabble ini akan terdiri dari beberapa bagian, yaitu proses pengenalan karakter Mandarin, dimana pemain akan diberikan sebuah karakter Mandarin dan pemain harus menyusun pelafalan atau intonasi yang tepat dalam pinyin dari karakter Mandarin tersebut.
\end{abstract}

Keywords : bahasa Mandarin, permainan, Scrabble, algoritma Directed Acyclic Word Graph

\section{PENDAHULUAN}

Bahasa Mandarin telah sangat umum digunakan dalam tingkat internasional. Hingga saat ini, Bahasa Mandarin masih terus berkembang dan sangat berguna dikarenakan Bahasa Mandarin menduduki peringkat pertama dan sering digunakan dalam dunia berbisnis dan wisata. Namun dalam pembelajaran Bahasa Mandarin pasti muncul berbagai macam kendala seperti kesulitan dalam penulisan karakter bahasa Mandarin, banyaknya karakter yang harus dipelajari serta intonasi dalam pelafalan Bahasa Mandarin. Permainan papan merupakan permainan dengan menggunakan media papan. Semakin banyak kosakata yang dimiliki seseorang, maka semakin mudah seseorang tersebut berkomunikasi dengan orang lain. Hal ini menggambarkan bahwa kosakata penting dalam kehidupan sehari-hari. Dalam keterkaitan 
tujuan dan usaha yang bisa dilakukan untuk mengatasi berbagai hambatan dalam belajar bahasa Mandarin terutama dalam hal pelafalan yang jarang diajarkan dengan spesifik di sekolah pada saat belajar. Maka perlu diberikan latihan dan pembimbingan kepada para siswa dalam mengembangkan pemahaman siswa dan peningkatan kompetensi berkomunikasi dalam bentuk lisan dan mempunyai kepercayaan diri dalam mengaplikasinya dalam belajar berbicara. Dalam peningkatan ketrampilan berbicara, pelafalan sebuah kata yang tepat merupakan suatu kemutlakan. Dalam berkomunikasi, seseorang perlu memastikan bahwa dia bisa melafalkan kata dengan tepat agar terjadi komunikasi yang harmonis, saling memahami apa yang diucapkan dan tidak menimbulkan kesalahpahaman dan salah interprestasi. Penyebab utama kesalahan dalam pelafalan bahasa Mandarin adalah perbedaan antara ucapan dan tulisan. Ketidakkonsistenan antara keduanya dan kurangnya latihan dalam melafalkannnya menyebabkan kesulitan dalam pelafalan dan komunikasi yang baik dalam bahasa Mandarin. Kompetensi pembelajaran di sekolah dalam hal pelafalan kosakata bahasa Mandarin kurang mendapatkan perhatian khusus, sehingga menyebabkan komunikasi yang terbatas karena faktor takut salah. Selanjutnya dalam meningkatkan kompetensi berkomunikasi baik dalam lisan maupun tulisan, maka setiap orang perlu memperluas kosakata, (Astuti et al., 2019). memiliki beberapa tahapan yang harus dilewati karena pada proses pencarian yang menggunakan metode ini sangat sensitive mengakibatkan hasil pencarian membantu untuk hasil yang dicari tahapan (Sugihariyadi \& Praja, 2020). Penelusuran kata pada DAWG seperti pada sebuah tree atau pohon data dimana setiap awalan dan akhiran digunakan bersama-sama untuk memperkecil jumlah ruang yang diperlukan untuk menyimpan kosa kata dan juga memperkecil waktu yang diperlukan untuk me-retrieve kata. Proses penyusunan kata dalam permainan Scrabble memerlukan algoritma yang disebut sebagai algoritma Directed Acyclic Word Graph (DAWG). Algoritma DAWG dapat menghemat ruang penyimpanan dan membantu proses mendapatkan kata yang akan dimainkan (Lasaprima et al., 2012). Penelusuran kata pada DAWG seperti pada sebuah tree atau pohon data dimana setiap awalan dan akhiran digunakan bersama-sama untuk memperkecil jumlah ruang yang diperlukan untuk menyimpan kosa kata dan juga memperkecil waktu yang diperlukan untuk me-retrieve kata.

\section{STUDI LITERATUR}

Permainan scrabble merupakan permainan menyusun kepingan huruf-huruf alfabet menjadi sebuah kata di atas sebuah papan berbentuk persegi yang dapat disusun secara mendatar atau menurun seperti teka-teki silang dan dapat dimainkan oleh 2 atau 4 orang anak. Permainan ini bertujuan membina penguasaan kosakata, melatih ejaan, dan melatih penguasaan struktur morfologis pada anak. Permainan scrabble beragam jenisnya dan pada umumnya digunakan untuk anak sekolah menengah pertama dan sekolah menengah atas. Namun belakangan ini permainan scrabble sudah mulai bisa digunakan untuk anak usia dini hingga anak berkebutuhan khusus. Akan tetapi scrabble yang digunakan bentuknya akan berbeda dengan scrabble untuk anak-anak usia sekolah menengah. (Muspawi et al., 2020). bahasa Mandarin merupakan salah satu bahasa asing yang dipelajari pada tingkat Sekolah Dasar hingga ke Perguruan Tinggi. Dalam pelajaran bahasa Mandarin, siswa diharapkan bisa terampil menggunakan bahasa Mandarin baik secara lisan maupun tulisan. Umumnya dalam pembelajaran bahasa terdiri dari empat keterampilan yaitu, mendengar 听力(Tīnglì), berbicara 口语 (Kǒuyǔ), membaca 阅读 (Yuèdú), dan menulis 写作 (Xiězuò). (Syech \& Gowa, 2020).

\section{METODE}

Teknik analisis data yang digunakan yaitu analisis deskriptif kualitatif, dan kuantitatif deskriptif (R et al., 2018). Berdasarkan. Langkah kerja dari penelitian ini dapat dirincikan sebagai berikut:

1. Pengumpulan Data.

This is an Creative Commons License This work is licensed under a Creative Commons 
Di tahap pertama, penulis mengumpulkan bahan-bahan yang diperlukan dalam penyusunan skripsi. Bahan tersebut dikumpulkan dari buku dan sumber-sumber lainnya di internet. Gambar-gambar objek yang diperlukan oleh perangkat lunak akan diambil dari buku-buku, majalah dan sumber-sumber lainnya di internet. Gambar objek pada buku dan majalah tersebut di-scan ke dalam komputer, kemudian di-edit dan disimpan dengan menggunakan aplikasi Adobe Photoshop C.S.

2. Analisis Sistem.

Tahap berikutnya ialah menganalisis kebutuhan-kebutuhan sistem. Sekali lagi, perangkat dan teknikteknik tertentu akan membantu penganalisis menentukan kebutuhan. Perangkat yang dimaksud ialah penggunaan diagram alir data untuk menyusun daftar input, proses, dan output fungsi bisnis dalam bentuk grafik terstruktur.

3. Perancangan Sistem.

Pada tahapan ini, akan dirancang sebuah aplikasi Mandarin Scrabble Game yang dapat dimainkan pada sebuah komputer. Kelebihan dari permainan yang dibuat ini dari permainan sebelumnya adalah bahwa aplikasi permainan yang dibuat ini menyediakan fasilitas bagi pemakai untuk mengganti dan menambah gambar objek yang akan digunakan dalam permainan.

4. Pembangunan Sistem.

Perangkat ajar ini dibangun dengan menggunakan bahasa pemrograman Microsoft Visual Basic 2010 dengan beberapa komponen standar seperti :
a. Button y
b. Picture Box
c. Label
d. Open Dialog Control
e. Save Dialog Control

Data daftar waktu tercepat akan disimpan ke dalam sebuah database yang dirancang dengan aplikasi Microsoft Access 2010.

5. Uji Coba Sistem.

Aplikasi permainan yang dibuat ini akan diuji terlebih dahulu, untuk mengetahui akurasi dari setiap proses pada permainan ini. Sebagian pengujian dilakukan oleh pemrogram sendiri, dan lainnya dilakukan oleh penganalisis sistem. Proses uji coba akan dilakukan dengan memberikan aplikasi yang dibuat kepada beberapa teman untuk diuji. Adapun kategori pengujian mencakup akurasi perhitungan nilai, lama reaksi sistem setelah pemain mengklik sebuah objek, akurasi perhitungan waktu beserta pengujian kesalahan (error debugging).

\section{III.1 Perancangan}

Perancangan sistem yang dibahas mencakup perancangan UML, perancangan flowchart, perancangan interface dan perancangan database.

\section{.1.1 Perancangan UML}


Diagram UML yang digunakan untuk mendeskripsikan dan memodelkan sistem mencakup use case diagram, activity diagram, class diagram dan sequence diagram.

\subsection{Use Case Diagram}

Untuk membantu mempermudah perancangan aplikasi, maka perlu digambarkan use case diagram dari aplikasi. Seperti terlihat pada gambar 1 dibawah, pemakai akan memilih tingkat kesulitan terlebih dahulu. Data tingkat kesulitan ini akan digunakan dalam tahapan menjalankan permainan. Setelah itu, pemakai akan memilih user yang diinginkan. Data user ini juga diperlukan dalam tahapan menjalankan permainan. Selain itu, pada tahapan menjalankan permainan juga akan dilakukan tahapan menyimpan nilai ke database dan menampilkan nilai yang diperoleh.

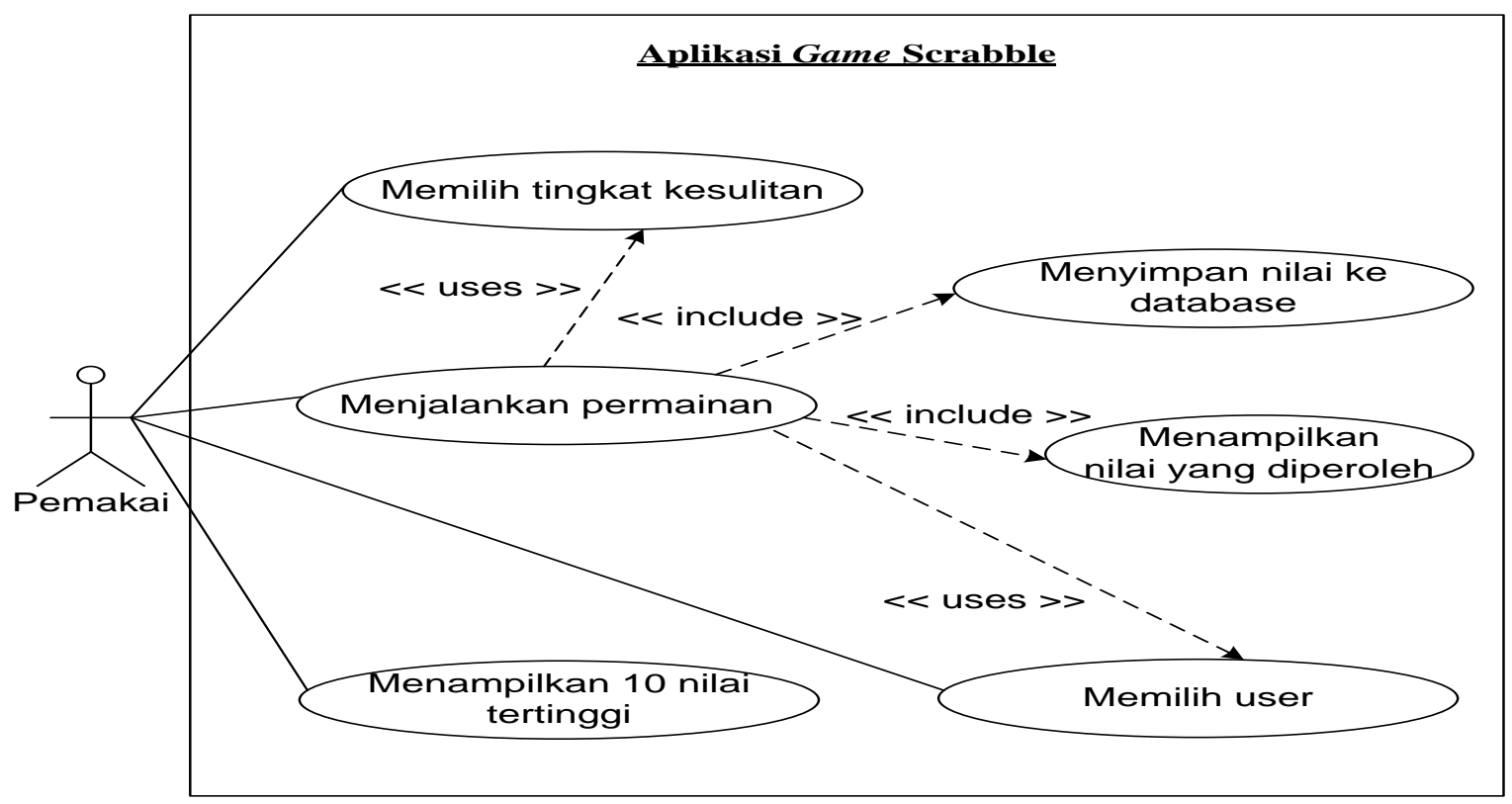

Gambar 1 Use Case Diagram dari Aplikasi

\subsection{Activity Diagram}




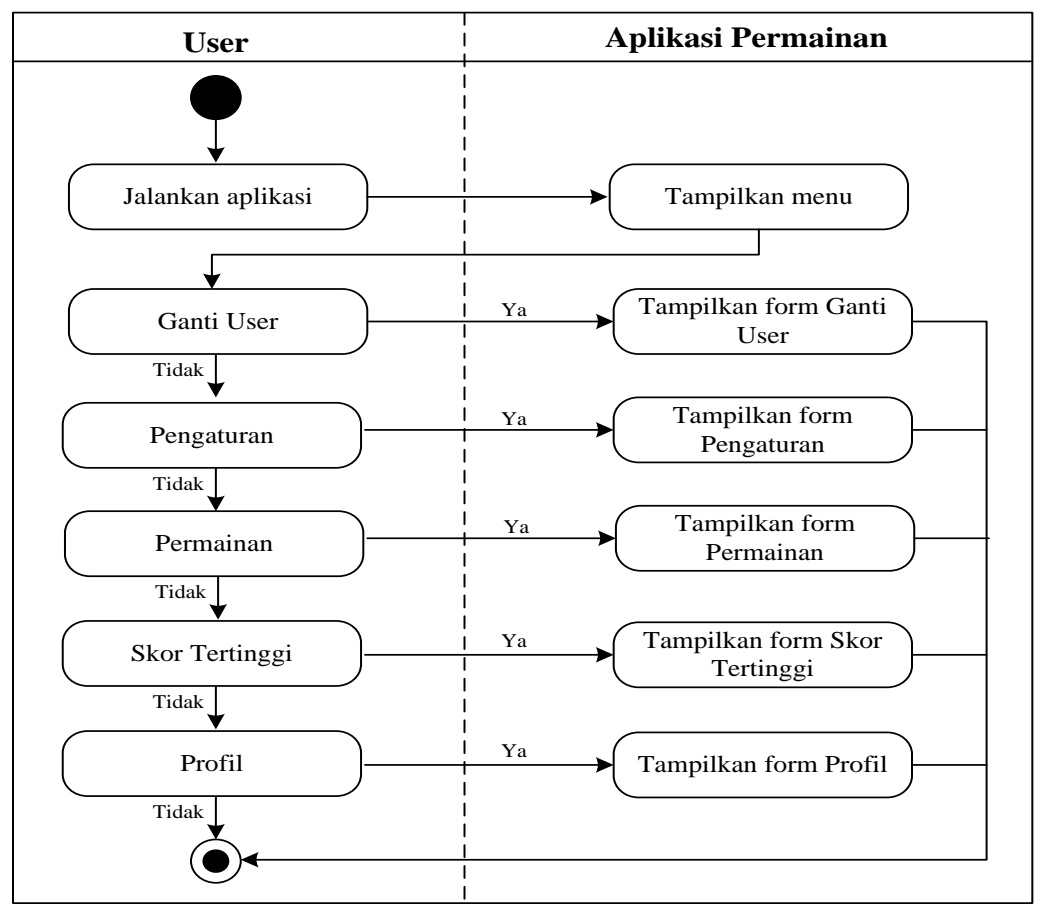

Gambar 2 Activity Diagram dari Form Main

Berdasarkan gambar 2 untuk memulai aplikasi user dapat membuka aplikasi ini, pada saat user membuka aplikasi ini, akan disajikan tampilan awal berupa menu utama. Di dalam menu utama terdapat beberapa link yaitu : permainan scrabble, Skor Tertinggi, pengaturan, profil, bantuan dan keluar. Pada menu utama user terlebih dahulu harus memilih link Ganti User sebelum dapat memulai permainan. User dapat memasukan nama user pada menu Ganti User ini.

\subsection{Class Diagram}

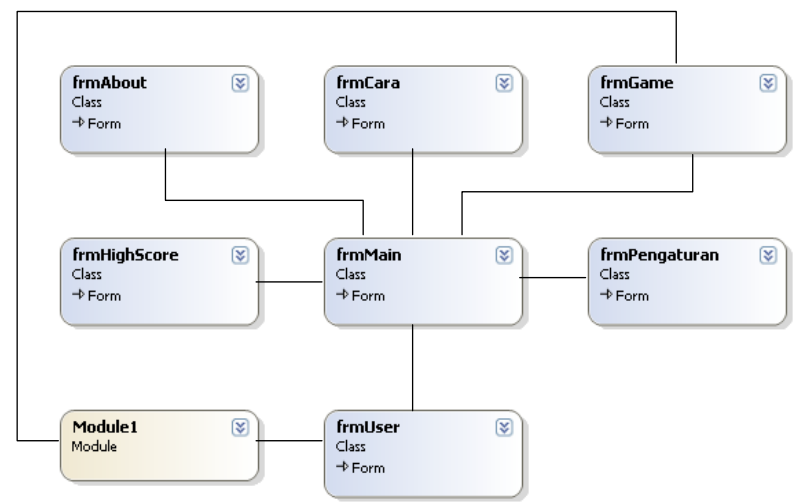

Gambar 3 Rancangan Class Diagram 
Berdasarkan gambar 3 diatas, aplikasi akan menampilkan form Main yang merupakan pusat kontrol dari segala aktifitas di dalam aplikasi, di dalam menu utama terdapat berbagai link yang dapat digunakan untuk menampilkan berbagai form yang terdapat pada perangkat lunak. Adapun form yang dapat ditampilkan dari form Main mencakup form Game, Cara, Pengaturan, User, HighScore dan Bantuan.

\subsection{Sequence Diagram}

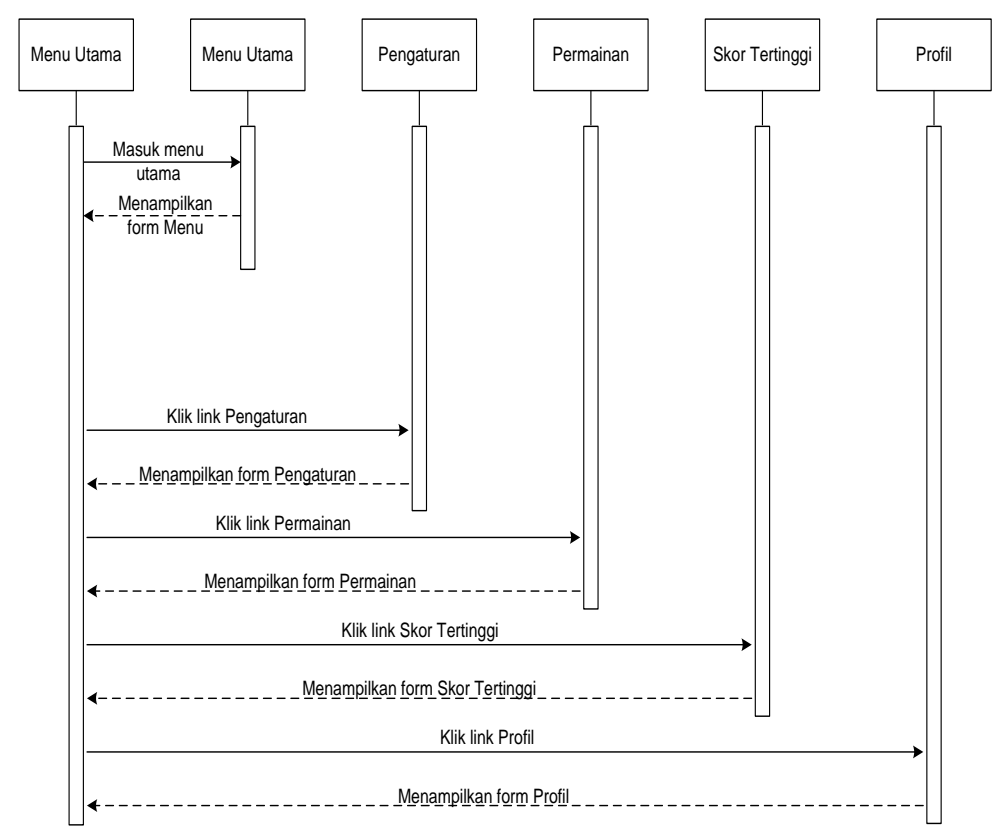

Gambar 4 Rancangan Sequence Diagram

Berdasarkan gambar 4 diatas, user pertama sekali membuka aplikasi dan akan melihat tampilan menu utama. Di dalam menu utama user dapat melakukan interaksi dengan memilih link-link yang disajikan oleh menu utama. Setelah mengklik link Pengaturan, maka aplikasi akan menampilkan form Pengaturan. Setelah mengklik link Permainan, maka aplikasi akan menampilkan form Permainan. Sementara itu, apabila user mengklik link Skor Tertinggi, maka aplikasi akan menampilkan form Skor Tertinggi. User juga dapat melihat bacaan mengenai pembuat aplikasi dengan memilih link Profil.

\subsection{Perancangan Flowchart}




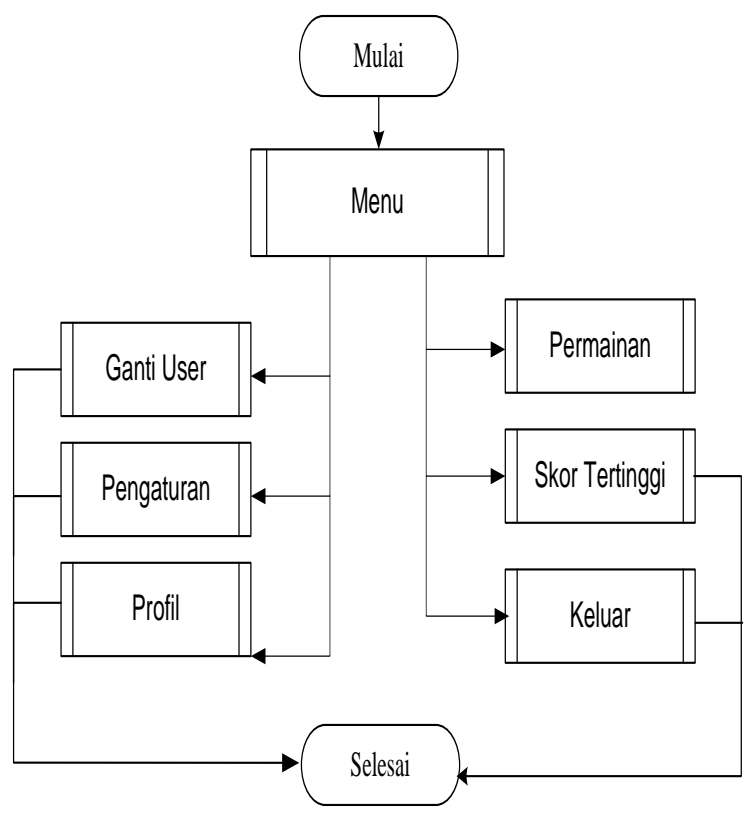

Gambar 5 Rancangan Flowchart Aplikasi

Berdasarkan gambar 5, pada saat aplikasi dijalankan dan masuk ke menu utama, user wajib terlebih dahulu memilih nama user sebelum dapat melanjutkan ke permainan. Setelah user dipilih maka user dapat memilih menu permainan untuk menuju ke permainan atau pilih tingkat kesulitan untuk mengatur tingkat kesulitan game atau melihat 10 nilai tertinggi ataupun melihat data tentang pembuat.

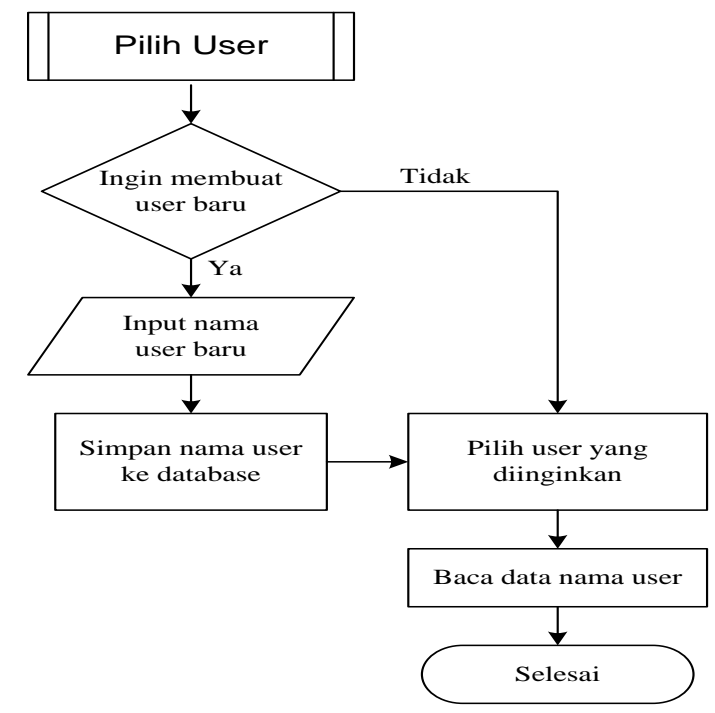

Gambar 6 Rancangan Flowchart Form User 
dapat dilihat bahwa jika pemain memilih link pilih user maka pemain dapat membuat user baru untuk disimpan datanya di database ataupun menggunakan $u$ ser yang sudah ada di database.

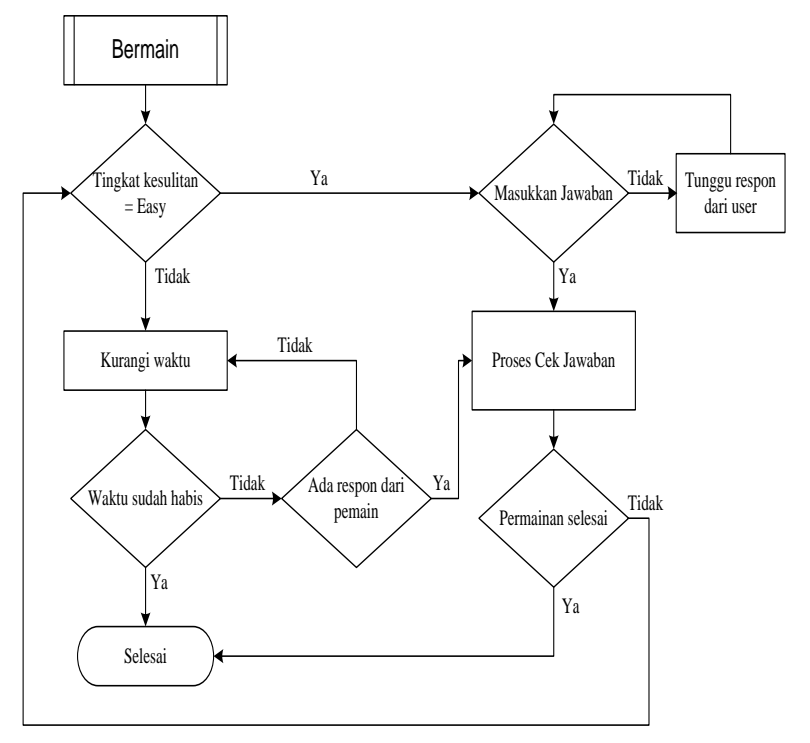

Gambar 7 Rancangan Flowchart Form Bermain

\section{PEMBAHASAN DAN HASIL}

Aplikasi Mandarin Scrabble Game bagi Pemula dengan Algoritma Directed Acyclic Word Graph yang dibuat menyediakan berbagai fitur yang memungkinkan seorang pemain untuk bermain Scrabble game pada sebuah komputer. 


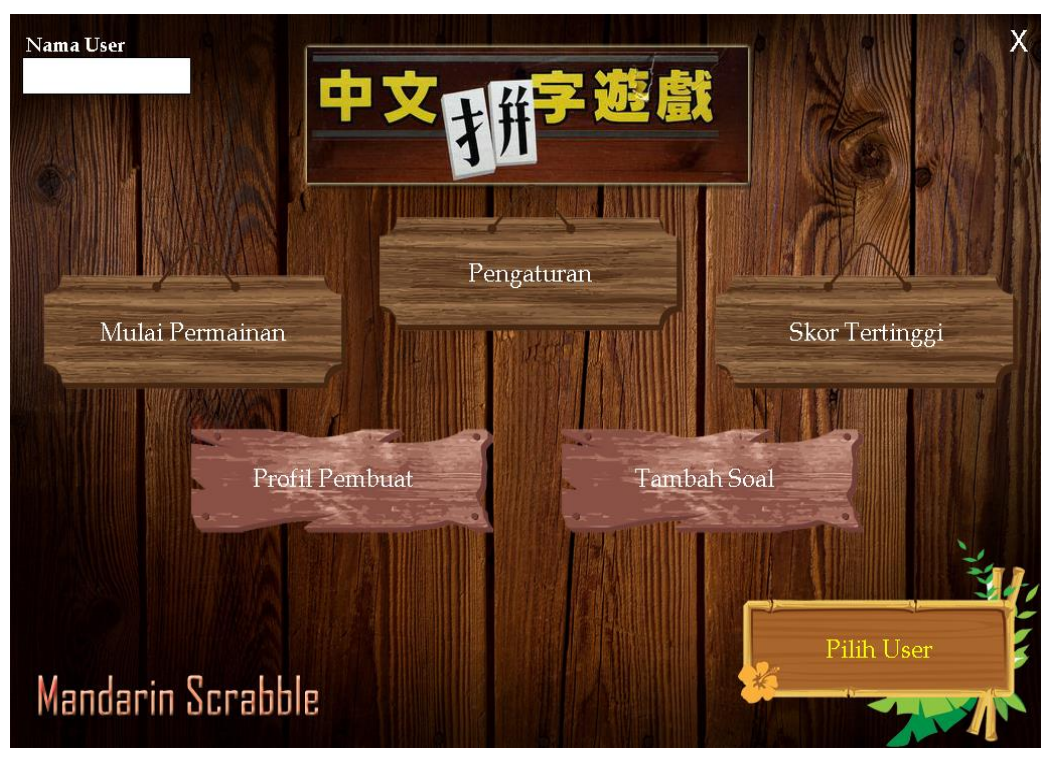

Gambar 8 Form Main

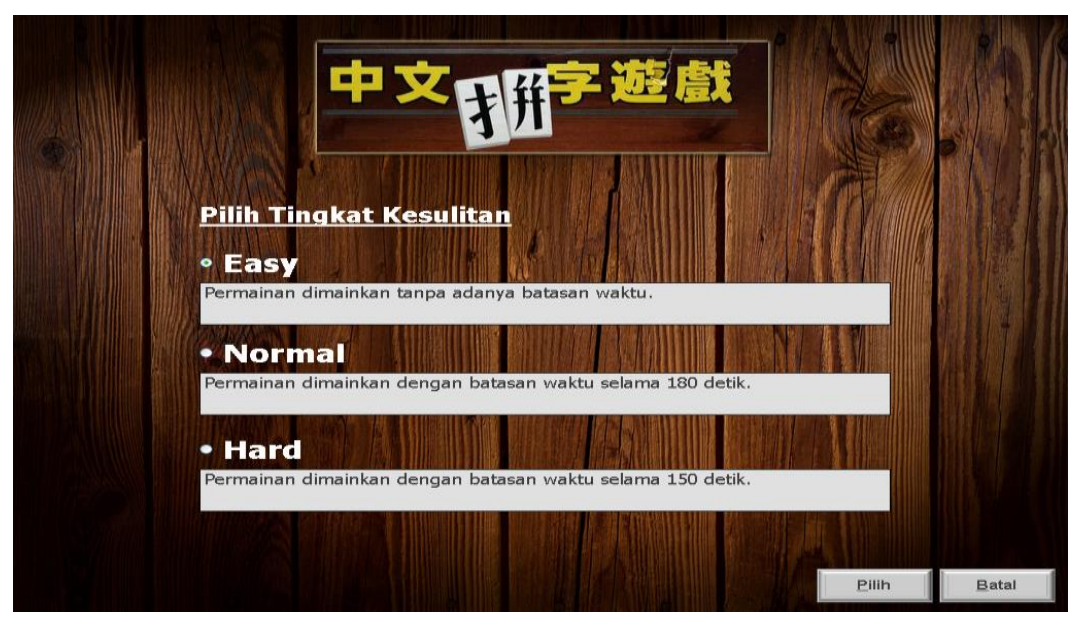

Gambar 9 Form Pengaturan

This is an Creative Commons License This work is licensed under a Creative Commons Attribution-NonCommercial 4.0 International License. 


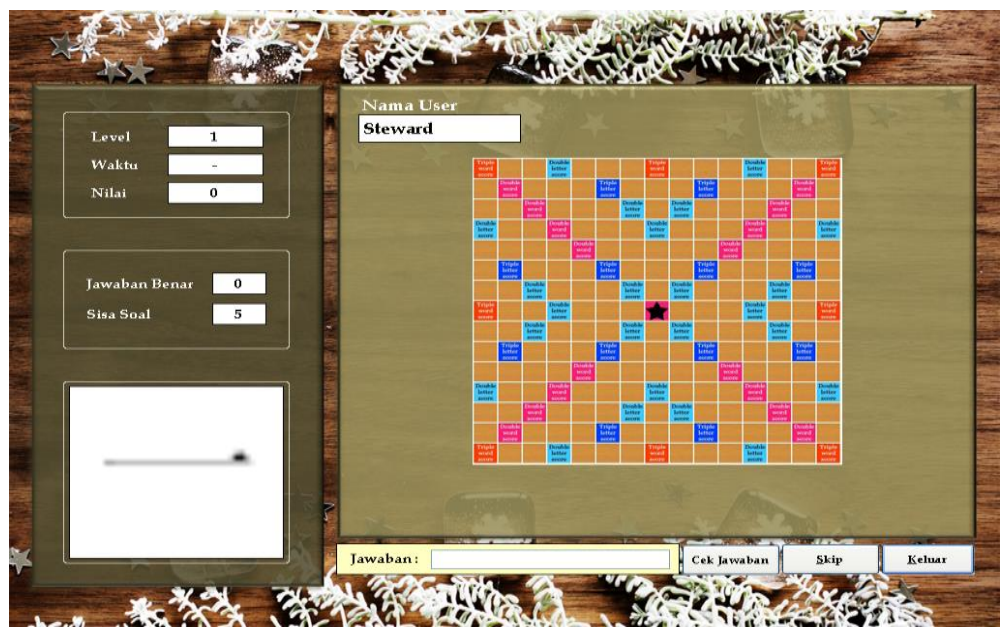

Gambar 10 Form Permainan

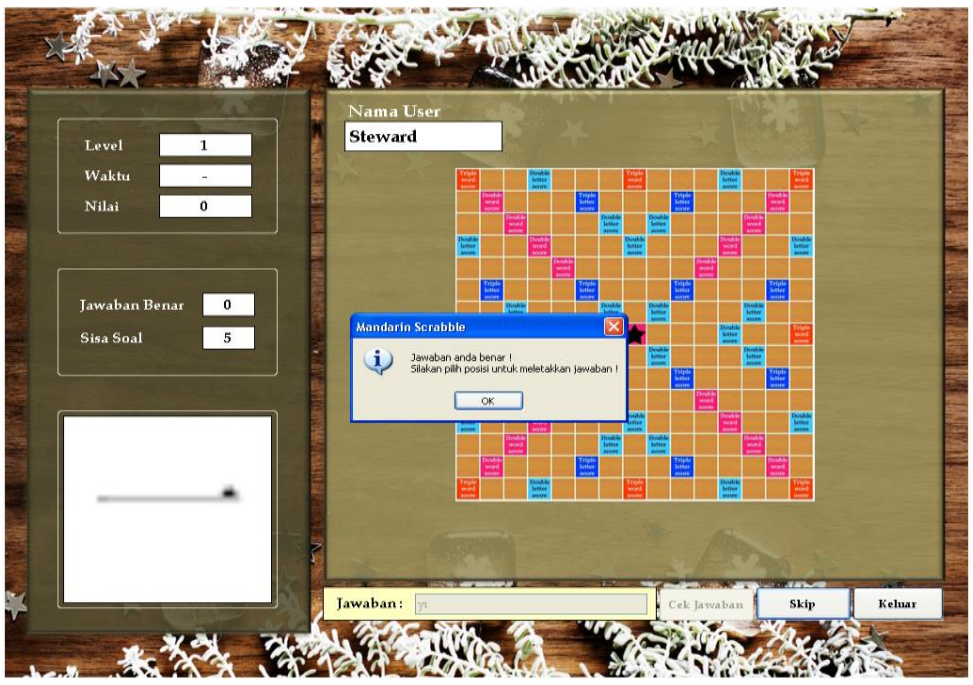

Gambar 11 Form Permainan Apabila Pemain Menjawab dengan Benar 


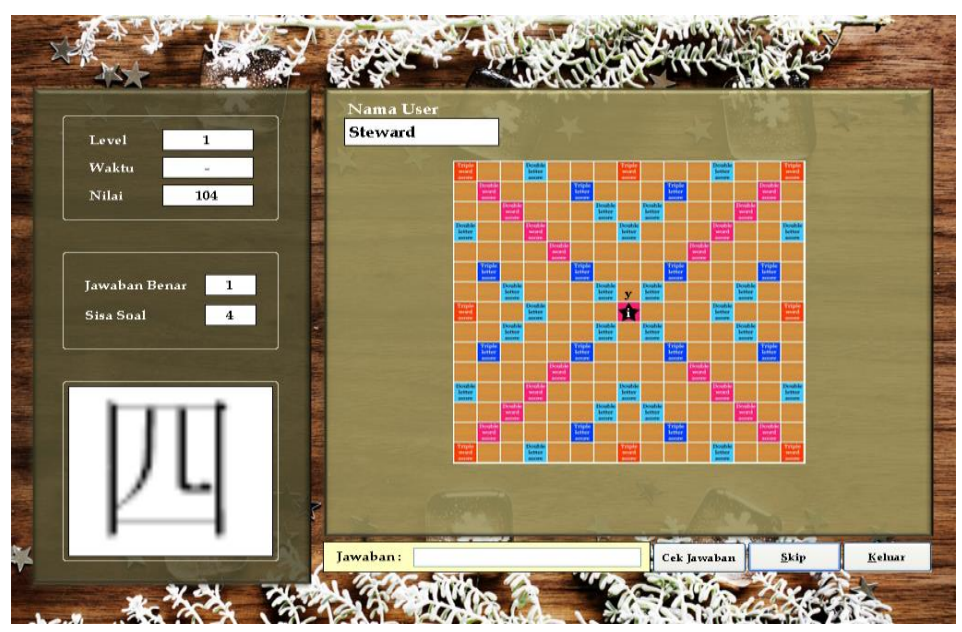

Gambar 12 Form Permainan Setelah Peletakan Karakter

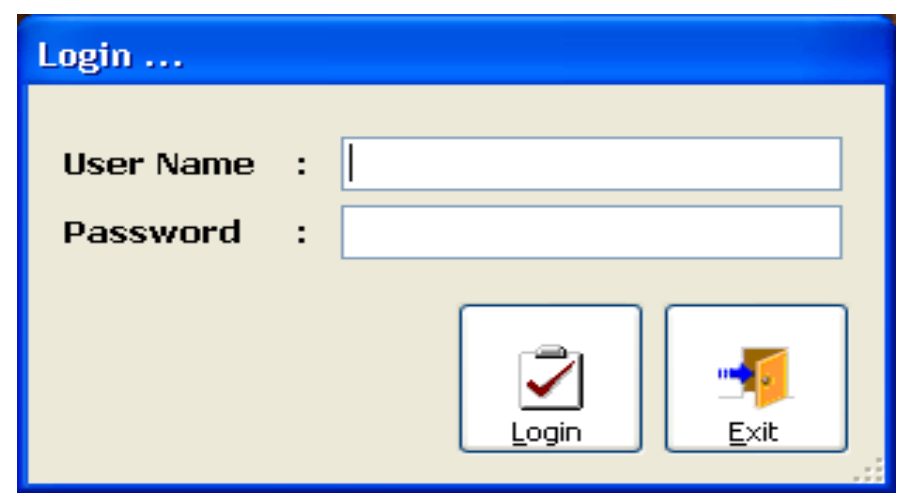

Gambar 13 Form 'Login'

\section{Pembahasan}

Kelebihan dari perangkat lunak yang dikonstruksi yaitu:

1. Aplikasi memiliki fasilitas pengaturan tingkat kesulitan sehingga pemain dapat mengatur tingkat kesulitan dari permainan.

2. Aplikasi menyediakan fasilitas penyimpanan data skor yang diperoleh pemain dalam permainan Scrabble sehingga pemain dapat menampilkan daftar skor tertinggi.

3. Aplikasi menyediakan fasilitas penambahan soal sehingga pemakai dapat menambahkan soal baru pada permainan Scrabble.

Sedangkan, kelemahan dari perangkat lunak yaitu: 
1. Software tidak menyediakan fasilitas perancangan tempat bermain (board) Scrabble, sehingga pemakai tidak dapat merancang board yang diinginkan.

2. Software tidak dapat digunakan untuk bermain melawan komputer.

3. Software tidak dapat menyediakan fasilitas pengetikkan pelafalan nada untuk karakter yang memiliki tulisan hanyu pinyin yang sama, namun memiliki nada intonasi yang berbeda.

4. Software tidak dapat mencari kata hanyu pinyin yang cocok untuk dimasukkan ke dalam papan permainan Scrabble, sehingga pemain harus melakukan proses skip secara manual untuk mencari soal yang cocok.

\section{Kesimpulan}

Directed Acyclic Word Graph dapat digunakan untuk mengecek peletakan kata yang diperbolehkan pada papan permainan dalam permainan Scrabble. Soal dalam permainan Mandarin Scrabble akan dihasilkan sesuai dengan tingkat kesulitan yang dipilih, dimana tingkat kesulitan mudah akan menggunakan soal dengan panjang hanyu pinyin yang agak pendek. Untuk menyimpan kata-kata atau membuat sebuah kamus data, algoritma directed acyclic word graph sangat mangkus dalam hal menghemat ruang penyimpanan tergantung kondisi kamus data. Strategi permainan scrabble yang memilih kata ditiap giliran hanya berdasarkan score tertinggi

\section{Referensi}

Astuti, D. S., Iqbal, M., Putra, R., Wiyanti, S., \& Sari, D. S. (2019). MELALUI PERMAINAN SCRABBLE. $3(2), 180-189$.

Lasaprima, A., Wibowo, A. T., Studi, P., Informatika, T., Informatika, F., Komputasi, I., Sains, F., \& Batu, T. B. (2012). Implementasi Algoritma Directed Acyclic Word Graph Dalam. 2012(Snati), 1516.

Muspawi, M., Suryani, I., \& Rahayu, A. Y. (2020). Penerapan Permainan Scrabble Untuk Meningkatkan Penguasaan Kosakata Anak. Jurnal Sains Sosio Humaniora, 4(1), 1-9. https://doi.org/10.22437/jssh.v4i1.9761

R, P. N., Sulaiman, \& S, A. A. (2018). Pengembangan Media Permainan Scrabble Berbasis Macromedia Flash Untuk Materi Menulis Karangan Sederhana Bahasa Indonesia Kelas III SDN Betiting. Widyagogik, 6, 13-28.

Sugihariyadi, M., \& Praja, M. J. K. (2020). DIRECTED ACYCLIC GRAPH MARKETING INFORMATION SYSTEMS MINE RESULTS IN PT . AMIR HAJAR KILSI REMBANG USING WIGHTED DIRECTED ACYCLIC GRAPH ALGORITHM.

Syech, C., \& Gowa, Y. (2020). MEMAHAMI TEKS DIALOG. 